\title{
Bazı silajlık mısır çeşitlerinde (Zea mays L.) bitkisel özelliklerinin belirlenmesi*
}

\author{
Nuri YILMAZ ${ }^{D}$, Osman AKMAN ${ }^{D}$ 2, Fatih ÖNER ${ }^{i} 1$ \\ ${ }^{1}$ Ordu Üniversitesi Ziraat Fakültesi Tarla Bitkileri Bölümü, Ordu \\ ${ }^{2}$ Tarım ve Orman Bakanlığı Çarşamba İlçe Müdürlüğü, Samsun \\ *Yüksek Lisans çalışmasından alınmıștır.
}

Alınış tarihi: 23 Aralık 2019, Kabul tarihi: 19 Mart 2020

Sorumlu yazar: Nuri YILMAZ, e-posta: y_nuri@hotmail.com

\section{Öz}

Bu çalışma, bazı silajlık mısır çeşitlerinde (Zea mays L.) bitkisel özelliklerinin belirlenmesi amaciyla 2018 yılında yürütülmüștür. Deneme Tesadüf Blokları Deneme Dsenine göre 3 tekrarlamalı olarak kurulmuştur. Materyal olarak 10 farklı silajlık mısır çeșidi (RX-9292, DKC- 955, 30 B 74, 36 K 61, Hido, 72 May 80, Otello, Reserve, Aga, Samada-07) kullanılmıştır. Araştırma sonucunda çiçeklenme süresi 70.0-77.3 gün, bitki boyu 269.3-322.1 cm, ilk koçan yüksekliği 100.0-156.1 cm, yaprak sayısı 10.614.2 adet, koçan sayısı 1.0-1.4 adet, sap çapı 23.7$27.2 \mathrm{~mm}$, yaprak ağırlığı 122.2-269.9 g, sap ağırlı̆̆ 345.6-648.5 g, koçan ağırlığı 424.8-848.5 g, kuru yaprak ağırlığı 59.0-86.7 g, kuru sap ağırlığ 94.3132.3 g, kuru koçan ağırlığı 229.7-321.7 g, arasında değişmiştir. Yapılan korelasyon analizi sonucunda en yüksek korelasyon yaprak ağırlığı ile kuru yaprak ağırlığı arasında görülmüştür. Çiçeklenme süresi bakımından Otello çeşidi öne çıkarken, bitki boyu, ilk koçan yüksekliği, yaprak sayısı ve yaprak ağırlığı bakımından Samada 07 ve 30 B 74 çeșitlerinin bölge için diğer çeşitlerden daha ümitvar olduğu düşünülmektedir.

Anahtar kelimeler: Silaj, mısır, bitkisel özellikler

Determination of plant characteristics of some silage maize (Zea mays $\mathrm{L}$.) varieties

Abstract
This study was conducted to reveal the
determination of plant characteristics of some silage
maize (Zea mays $\quad$ L.) varieties in 2018. The

experiment was laid out in the randomized blocks design with 3 replications. In the current study, 10 different silage maize varieties (RX-9292, DKC- 955, 30 B 74, 36 K 61, Hido, 72 May 80, Otello, Reserve, Aga, Samada-07) were used as experimental materials. The variation of the investigated traits among the mazie varieties were as follows, flowering period ranged between 70.0-77.3, day, plant height 269.3-322.1 cm, first ear height 100.0-156.1 cm, number of leaves 10.6-14.2, number of stubs 1.0-1.4 pieces, stalk diameter 23.7-27.2 $\mathrm{mm}$, leaf weight 122.2-269.9 g, stem weight 345.6-648.5 g, cob weight 424.8-848.5 g, dry leaf weight 59.0-86.7 g, dry stem weight 94.3-132.3 g, dry ear weight 229.7321.7 g. According to the correlation analysis, the highest correlation was found between leaf weight and dry leaf weight. As a result of the data, while the variety of Otello having importance in terms of flowering time, Samada 07 and 30 B 74 varieties are considered more promising than the other varieties for the region in terms of plant height, height of the first stub, number of leaves and leaf weight.

Key words: Silage, maize, plant characteristics

\section{Giriş}

Binlerce yıldır tarımı yapılan mısır bitkisinin kökeni Amerika kıtası olup buradan diğer kıtalara yayıldığı bilinmektedir. Amerika Birleşik Devletleri'nde yapılan kazılarda bulunan misır kalıntılarının 5 bin yıllık oldukları belirlenmiştir. 1954 yılında da Meksika'da yapılan kazılarda ise toprağın derinliklerinde yaklaşık 7 bin yıllık olduğu tespit edilen mısır çiçek tozları bulunmuştur (Geçit vd., 2009). Günümüzde ise Misır bitkisi dünyada 
Antartika kıtası haricinde, hemen hemen her iklim kuşağında tarımı yapılabilen bir sıcak iklim tahılıdır. Türkiye'de ana ürün ve ikinci ürün olarak üretimi gerçekleştirilen mısır bitkisi buğday ve arpadan sonra en geniş ekim alanına sahip olan tahıldır. Mısır üretimindeki belirgin artış 1980'li yıllardan sonra kaydedilmiştir. Bunun nedeni misır üretiminin desteklenmesi, modern misır üretim tekniklerinin uygulanması, hibrit tohum kullanımının artması, sulanan alanlarda misır üretiminin yapılması ve gübre kullanımının artmasıdır. Özellikle sulama projeleri neticesinde sulanan alanlarda üretiminin yaygınlaşmasıyla Türkiye'de mısır üretiminde önemli bir artış olmuştur. Mısır hem insan ve hayvan beslenmesinde hem de endüstri de ham madde olarak kullanılan bir tahıldır. Sap ve yaprakları hayvan yemi olarak kullanılmaktadır. Bitkinin saplarından kâğıt ve hasır işleri yapımında da faydalanılmaktadır. Haşlanmış haliyle konserve olarak, işlendikten sonra da çerez olarak da tüketilmektedir. Son yıllarda mısırın üretim miktarındaki artışla birlikte; yem, yağ ve tatlandırıcı sektörü kullanımın da da artış göstermiştir(Emeklier, 2002). Dünyada üretilen misırın insan beslenmesinde \% 27'si, hayvan yemi olarak ise \% 73'ü değerlendirilmektedir. Üçüncü dünya ülkelerinde misırın \% 46'sı hayvan beslenmesinde, \% 54'ü ise insan beslenmesinde ve endüstri ham maddesi olarak kullanılırken, gelişmiş ülkelerde \% 90'ı hayvan beslenmesinde, \% 10'u da insan beslenmesinde ve endüstride kullanılmaktadır (Öz ve ark., 2017). Ülkemizde ise mısır \% 70 oranında hayvan yemi ve yem ham maddesine aittir. Mısır en çok büyükbaş-küçükbaş hayvan yemlerinde ve kanatlı hayvan sektöründe kullanılmaktadır. Ülkemizde mısırın kullanıldı̆̆ı diğer sektör ise yaklaşılk \% 20 ile nişasta sektörüdür ve bunu mısır yağı ve etanol üretimi gibi diğer endüstriyel sektörler takip etmektedir (Çevik, 2012). Son yıllarda misırın, birim alandan elde edilen veriminin fazla olması, silaj yapımına ugunluğu ve misır silajının besleme değerinin yüksek ve kaliteli olması gibi nedenlerden dolayı silaj üretimi amacıyla ekim alanı artmıştır. İnsan beslenmede ve tarımsal endüstride önemli bir paya sahip olan misır, son yıllarda silajlık olarak hayvan beslemesinde de kullanılarak en önemli kaba yem hâline gelmiștir (Çete ve Sarıcan, 1998). Tarımsal anlamda gelişmiş olan ülkelerde mısır silajı büyükbaş hayvan besiciliğnde proteince zenginleştirilerek çok yoğun olarak kullanılan ekonomik bir yemdir (Alçiçek ve Karaayvaz, 2003). Silajlık mısır üretimi, o bölgede bulunan çiftliklerinin yoğunluğuna göre doğru orantılı olarak artış göstermektedir. Silajlık mısır üretimini ticari anlamda yapan üreticiler balyalama yaparak silajı ülkemizin farklı bölgelerine pazarlayabilmektedirler. Son on yll içerisinde silajlık mısır ekim alanları ve üretim miktarı yaklaşık olarak \% 50 oranında artış göstermiştir. 2018 yılında silajlık mısırın ekim alanı yaklaşık 4,6 milyon dekardır. Toplam silajlık mısır üretimi ise 23,1 milyon tondur (Anonim, 2019). Silajlık misır verimini artırmanın temel koşulu yetiştirildiği bölgenin ekolojisine uygun çeşitlerin geliştirilmesidir. Uygun çeşitler kendi ekolojilerinde demastrasyona alınmalıdır (Kapar ve Öz, 2006). Tüm bitkilerdeki gibi mısır tarımında da verim çeşit ve ekoloji yani çevre adaptasyonuna bağımlıdır. Bu sebeple farklı ekolojik koşullarda yürütülecek adaptasyon çalışmaları ile koşullara en uygun çeșitlerin belirlenmesi büyük önem taşımaktadır. Çünkü mısır çeşitlerinin farklı ekolojilerde agronomic özellikleri farklılı gösterebilir (Argillier ve ark., 2000).

$\mathrm{Bu}$ çalışmanın amacı; Samsunda iki büyük ovadan biri olan Çarşamba ovasında bazı silajlık mısır çeşitlerinin bitkisel özelliklerinin belirlenmesidir. Yapılan araştırmada, silajlık olarak bölgeye uyum sağlayabilecek üretim izinli veya tescilli mısır çeşitlerinin bitkisel özelliklerinin belirlenerek araştırıcılara ve silaj tarımına ihtiyaç duyan çiftçilere faydalı teknik bilgilerin verilmesi ve çeşit önerilerinin yapılması amaçlanmıştır.

\section{Materyal ve Yöntem}

\section{Materyal}

Araștırmada özel tohumluk firmalarından sağlanan 10 misır çeşidi (RX-9292, DKC- 955, 30 B 74, 36 K 61, Hido, 72 May 80, Otello, Reserve, Aga, Samada07) deneme materyali olarak kullanılmıştır. Araştırmada kullanılan çeşitlerin isimleri, temin edildiği kuruluşlar, olum süreleri ve FAO olum grupları Çizelge 1'de gösterilmiştir. $\mathrm{Bu}$ çalışma Karadeniz Tarımsal Araştırma Enstitüsü (KTAE)'nün Çarşamba Ambarköprü deneme istasyonunda 2018 yılında yürütülmüștür. Deneme yeri Samsun'a $25 \mathrm{~km}$ uzaklıkta Samsun-Çarşamba karayolu üzerinde, deniz seviyesinden yaklaşık $4 \mathrm{~m}$ yükseklikte olup, drenaj sorunu bulunmamaktadır. Araştırma yapılan toprakların bazı fiziksel ve kimyasal özelliklerini belirlemek amacıyla, ekim öncesi deneme alanından alınan toprak örnekleri Karadeniz Tarımsal Araștırma Enstitüsü, Toprak bitki $\mathrm{Su}$ analiz laboratuvarında analiz edilmiştir. 
Çizelge 1 Araştırmada kullanılan çeşitler, temin edildiği kuruluşlar, olum süreleri ve FAO olum grupları

\begin{tabular}{|c|c|c|c|c|}
\hline Sira no & Çeşit & Temin edilen kuruluş & Olum süresi (gün) & FAO olum grubu \\
\hline 1 & RX-9292 & May-Agro & 130 & FAO 700 (çok geç) \\
\hline 2 & DKC-955 & Dekalb & $110-115$ & FAO 800 (çok geç) \\
\hline 3 & 30 B 74 & Pioneer Toh. & 120 & FAO 700 (çok geç) \\
\hline 4 & $30 \mathrm{~K} 61$ & Pioneer Toh. & $90-100$ & FAO 550 (orta) \\
\hline 5 & Hido & May-Agro & $100-110$ & FAO 700 (çok geç) \\
\hline 6 & 72 May 80 & May-Agro & $100-110$ & FAO 700 (çok geç) \\
\hline 7 & Otello & Poltar Tarım & $115-120$ & FAO 600 (geç) \\
\hline 8 & Reserve & Syngenta Tarım & $100-105$ & FAO 700 (çok geç) \\
\hline 9 & Aga & Mısır AE\&Batı Akdeniz AEM & 135 & FAO 720 (çok geç) \\
\hline 10 & Samada-07 & Misır AE\&Karadeniz TAEM & 130 & FAO 700 (çok geç) \\
\hline
\end{tabular}

Deneme alanının toprağı killi tınlı (İşba \% 66.00), hafiif alkali (pH: 7.86), tuzsuz (Toplam tuz: 0.05), orta kireçli $\left(\mathrm{CaCO}_{3} \%\right.$ : 6.76), fosfor miktarı çok az $\left(\mathrm{P}_{2} \mathrm{O}_{5}: 2.52 \mathrm{~kg} / \mathrm{da}\right)$, potasyum miktarı yüksek (K2O: $94.00 \mathrm{~kg} / \mathrm{da})$ ve organik maddece orta $(\% 2.26)$ yapıdadır.

Samsun ilinin iklimi, Orta Karadeniz Bölgesi'nin ılıman iklim özelliklerini yansıtmaktadır. Uzun yıllar ortalamalarına göre yağışların büyük bir kısmı kış ve sonbaharda düșerken, özellikle yaz aylarında düșen yağışlar bitkisel üretim için yetersizdir

Yetiştirme dönemine (Nisan-Ekim) ait uzun ylllar ortalama sicaklık $19.3{ }^{\circ} \mathrm{C}$ olup, 2018 yllında 20.6 ${ }^{\circ} \mathrm{C}$ 'dir. İklim verileri içerisinde en dikkat çekici olan ve denemenin yürütüldüğü yıllarda aylar bazında en önemli farklılıkların rastlandığı veri yağış değerleridir. Mısırın yetişme döneminde uzun yıllar ortalaması olarak yağış miktarı toplam $493.5 \mathrm{~mm}$, 2018 yılında ise 534.5 mm'dir. 2018 yllinda temmuz, ağustos, eylül ve ekim ayları uzun yllar vejetasyon ortalamasından daha yağışlı geçmiştir. Yetiştirme döneminde uzun yıllar nispi nem ortalaması $\% 79.6$ iken, 2018 yılında \% 78.4 olmuştur. Ortalama nispi nem 2018 yllında uzun yillar ortalamasından daha düşük olarak kaydedilmiştir.

\section{Yöntem}

Araştırma Tesadüf Blokları deneme metodunda 3 tekrarlamalı olarak yürütülmüştür. Deneme arazisi sonbaharda pullukla işlenmiş, ekimden önce diskaro ve tırmık çekilerek tohum yatağı hazırlanmıştır. Ayrıca ekimden önce yabancı otlar için kimyasal mücadele uygulanmıştır. Ekim 26.04.2018 tarihinde, $70 \mathrm{~cm}$ aralıklarla açılan sıralara sıra üzeri $20 \mathrm{~cm}$ olacak şekilde elle yapılmıştır. Her parselde $5 \mathrm{~m}$ uzunluğunda 4 sıra yer almış, parseller arasında $1 \mathrm{~m}$ bloklar arasında ise $2.5 \mathrm{~m}$ boșluk bırakılmıștır. Denemede $20 \mathrm{~kg} / \mathrm{da}$ saf azot ve $10 \mathrm{~kg} / \mathrm{da}$ fosfor $\left(\mathrm{P}_{2} \mathrm{O}_{5}\right)$ olacak şekilde gübreleme yapılmıştır. Azotun yarısı ekimle birlikte yarısı da tepe püskülü gösterme dönemindeverilmiştir.

Ekimden önce yabancı otlar için kimyasal mücadele uygulanmıştır. Denemede sıra üzerine çıkışlar garanti olması için her ocağa 2 tohum bırakılmıştır. Seyreltme-tekleme işlemi 20.05.2018 tarihinde, gerek yabancı otları kontrol etmek gerekse toprağın havalanmasını sağlamak amacıyla çapalama ve boğaz doldurma işlemi 30.05.2018 tarihinde yapılmıştır. Denemede yabancı ot yoğunluğundaki artışa bağlı olarak çapa ve el ile parsellerdeki yabancı otlar gerek duyuldukça temizlenmiştir. Denemede 30 Nisan 2018 tarihinde yağmurlama sulama, 21 Mayıs, 05 Haziran, 02 Temmuz ve 01 Ağustos 2018 tarihlerinde damla sulama yapılmıştır.

Hasat işlemi taneler süt olum döneminde iken her parselde parsel başlarından $40 \mathrm{~cm}$ ve parsel kenarlarından birer sıra kenar tesiri atıldıktan sonra kalan kısımdaki bitkiler içerisinden rastgele seçilen 5 bitki gözlem ve ölçümler için alınmıştır.

Araştırmada Çiçeklenme Süresi (gün), Bitki Boyu (cm), İlk Koçan Yüksekliği (cm), Yaprak Sayısı (adet), Koçan Sayısı (adet), Sap Çapı (mm), Yaprak Ağırlığı (g), Sap Ağırlı̆̆ı (g), Koçan Ağırlığı (g), Kuru Yaprak Ağırlığı (g), Kuru Sap Ağırlığı (g), Kuru Koçan Ağırlı̆̆ı (g) gibi özellikler incelenmiştir.

Araştırma sonucunda elde edilen veriler SPSS 22.0 istatistik paket programı kullanılarak Tesadüf Blokları Deneme Desenine gore varyans analizine tabi tutulmuştur. Önemlilik gösteren ortalamalar arası farklılıkların karşılaştırılmasında Duncan çoklu karşılaştırma testi kullanılmıştır. Korelasyon analizi de SPSS 22.0 paket programında Pearson'a göre yapılmıştır.

\section{Bulgular ve Tartışma}

İcelenen özellikler arasında yapılan varyans analizi sonuçları ile kareler ortalama değerleri Çizelge 2'de verilmiştir. 
Çizelge 2. İncelenen bazı özelliklerin varyans analiz tablosu kareler ortalamaları ve önemlilik kontrolü

\begin{tabular}{|c|c|c|c|c|c|c|c|}
\hline VK & SD & CSS & $\mathrm{BB}$ & İKY & YS & KS & $\mathrm{SC}$ \\
\hline Blok & 2 & $9.700^{* *}$ & $109.280 ̈ \mathrm{~d}$ & 508.07* & 0.50 öd & 0.69 öd & $0.66 \ddot{d}$ \\
\hline Çeşit & 9 & $12.00^{* *}$ & $860.12 *$ & $869.74^{* *}$ & $3.59^{*}$ & 0.09 öd & 3.12öd \\
\hline VK & & YA & SA & KA & KYA & KSA & KKA \\
\hline Blok & 2 & 1148öd & 9290öd & 6491öd & 99.2öd & $196.3^{*}$ & 298.3öd \\
\hline Çeşit & 9 & $6520^{*}$ & 32080öd & 40984* & 238.8öd & 434.4öd & 2583.6öd \\
\hline
\end{tabular}

VK: Varyasyon Kaynakları, SD: Serbestlik Derecesi, ÇS: Çiçeklenme Süresi, BB: Bitki Boyu, İKY: İlk Koçan Yüksekliği, YS: Yaprak Sayısı, KS: Koçan Sayısı, SÇ: Sap Çapı, YA: Yaprak Ağırlı̆̆ı, SA: Sap Ağırlığı, KA: Koçan Ağırlığı, KYA: Kuru Yaprak Ağırlı̆̆ı, KSA: Kuru Sap Ağırlığı, KKA: Kuru Koçan Ağırlı̆̆ı.

Çizelge 3. Mısır çeşitlerinin çiçeklenme süresi, bitki boyu, ilk koçan yüksekliği, yaprak sayısı, koçan sayısı ve sap çapına ait ortalamaları.

\begin{tabular}{|c|c|c|c|c|c|c|}
\hline Çeşitler & $\begin{array}{l}\text { Çiçeklenme } \\
\text { süresi (gün) }\end{array}$ & Bitki Boyu $(\mathrm{cm})$ & $\begin{array}{l}\text { İlk Koçan } \\
\text { Yük. (cm) }\end{array}$ & $\begin{array}{c}\text { Yaprak } \\
\text { Say. (adet) }\end{array}$ & $\begin{array}{c}\text { Koçan } \\
\text { Say. (adet) }\end{array}$ & Sap Çapı (mm) \\
\hline 30 B 74 & $77.3 \mathrm{a}$ & $314.4 \mathrm{ab}$ & $156.1 \mathrm{a}$ & $14.2 \mathrm{a}$ & 1.0 & 25.3 \\
\hline 36 K 61 & $73.3 \mathrm{de}$ & 294.8 bc & $125.6 \mathrm{bc}$ & $11.7 \mathrm{bc}$ & 1.0 & 26.0 \\
\hline 72 MAY 80 & $72.0 \mathrm{e}$ & $302.7 \mathrm{abc}$ & $118.9 \mathrm{bcd}$ & $11.2 \mathrm{c}$ & 1.1 & 26.1 \\
\hline RX-9292 & $74.0 \mathrm{~cd}$ & $269.3 \mathrm{~d}$ & $118.3 \mathrm{~cd}$ & $11.0 \mathrm{c}$ & 1.2 & 25.6 \\
\hline AGA & $74.7 \mathrm{bcd}$ & 290.4 bcd & $138.9 \mathrm{ab}$ & 11.9 bc & 1.3 & 27.2 \\
\hline DKC-955 & $75.3 \mathrm{bc}$ & $315.0 \mathrm{ab}$ & $128.9 \mathrm{~cd}$ & $12.2 \mathrm{bc}$ & 1.4 & 25.2 \\
\hline HİDO & $74.7 \mathrm{bcd}$ & $281.7 \mathrm{~cd}$ & $126.1 \mathrm{bc}$ & $11.9 \mathrm{bc}$ & 1.4 & 23.7 \\
\hline OTELLO & $70.3 \mathrm{f}$ & $286.1 \mathrm{~cd}$ & $129.5 \mathrm{bc}$ & $10.6 \mathrm{c}$ & 1.0 & 27.2 \\
\hline RESERVE & $73.3 \mathrm{de}$ & $285.7 \mathrm{~cd}$ & $100.0 \mathrm{~d}$ & $11.2 \mathrm{c}$ & 1.0 & 26.1 \\
\hline SAMADA-07 & $76.0 \mathrm{ab}$ & $322.1 \mathrm{a}$ & $155.5 \mathrm{a}$ & $13.2 \mathrm{a}$ & 1.1 & 25.2 \\
\hline Genel ort. & 74.1 & 296.2 & 129.8 & 11.9 & 1.1 & 25.7 \\
\hline$\% \mathrm{VK}$ & 1.24 & 4.41 & 8.15 & 7.63 & 20.61 & 6.55 \\
\hline
\end{tabular}

Çizelge 2 incelendiğinde ele alınan parametreler bakımından çeşitler arasında çiçeklenme süresi ve ilk koçan yükseklği bakımından \%1 önem seviyesinde; bitki boyu, yaprak sayısı, yaprak ağırlığı ve koçan ağırlığı bakımından ise \%5 önem seviyesinde fark olduğu belirlenmiştir. Diğer incelenen özellikler bakımından ise çeşitler arasındaki fark istatistiksel olarak önemsiz bulunmuştur.

\section{Çiçeklenme süresi}

Denemede kullanılan Mısır çeşitlerinin çiçeklenme sürelerine ait ortalamalar ve oluşan gruplar Çizerlge 3'de verilmiştir. Çizelge 3 incelendiğinde en uzun çiçeklenme süresi 77.3 gün ile $30 \mathrm{~B} 74$ çeşidinde belirlenirken, SAMADA-07 çeşidi 76.0 gün ile aynı istatistiki grupta yer almıştır. En düşük çiçeklenme süresi ise 70.3 gün ile OTELLO çeşidinde belirlenmiştir. İstatistiki analiz sonucunda ortalama çiçeklenme süresi 74.1 gün olarak belirlenmiştir. Araştırmadan elde ettiğimiz çiçeklenme süreleri değerleri, ülkemizin değişik bölgelerinde çeşitlerin çiçeklenme sürelerinin tespit edildiği araştırmalardan, Eralp (2007) (47.2-56.5 gün), Han (2016) (63.6-68.3 gün) ve Öner ve Güneş (2019) (55-65 gün)'in sonuçlarından yüksek çlkarken, Öner ve ark. (2011b) (71-74 gün), Öner (2017) (68-80 gün) ve Kabakçı (2014) (67.4-76.7 gün)'nın değerleriyle benzerlik göstermiş, Gençtürk (2007)
(79.3-94.7 gün)'ün deneme değerlerinden düșük bulunmuştur. Çiçeklenme süresi çeşitlerin vejetasyon süreleri açısından fikir veren en önemli özelliktir. Mısır çeşitlerinin çiçeklenme süreleri, olum grubuna ve yetiştiği bölgeye göre önemli farklılık göstermektedir (Öner, 2015).

\section{Bitki boyu}

Çizelge 3 incelendiğinde, en yüksek bitki boyu 322.1 cm ile SAMADA-07 çeşidinde belirlenmiş, DKC-955 $(315.0 \mathrm{~cm}), 30$ B $74(314.4 \mathrm{~cm})$ ve 72 MAY 80 (302.7 $\mathrm{cm}$ ) çeşitleri ile aynı istatistiki grup içerisinde yer almıştır. En düşük bitki boyu $269.3 \mathrm{~cm}$ ile RX-9292 çeşidinden elde edilmiştir. Çeşitlere ait ortalama bitki boyu $296.2 \mathrm{~cm}$ bulunmuştur. Elde ettiğimiz bitki boyu değerleri Yıldız ve ark. (2017), 3.27-3.77 m, Han (2016), 286.7-315.6 cm, Ergül (2018), 298341, Öner ve Güneș (2019), 309.93-365.20 cm'in araştırma sonuçlarından daha düşük bulunurken, Yozgatlı ve ark. (2019), 2.17-2.73 m ile Akdeniz ve ark. (2003) 143.7-242.6 cm'nın sonuçlarından yüksek bulunmuştur. Öner ve ark. (2011a), 301-330 cm, Öner ve ark. (2011b) 270-325 cm, Çaçan ve İşikten (2019), 248.7-282.7 cm'in araştırma sonuçlarıyla benzerlik göstermiştir. Mısır silajında amaç birim alandan daha fazla yeşil aksam elde edebilmektir. Bitki boyunun silajlık misırda verimi doğrudan etkilediği ve bitki boyunun çevre ve yetiştirme şartlarından etkilenen kalıtsal bir özellik 
olduğu bilinmektedir (Kavut, 2009). Elde ettiğimiz bitki boyu değerleri ile araştırma sonuçları arasındaki farklılıkların hem çalışmaların yürütüldüğü ekolojilerdeki iklim ve toprak özelliklerinden hem de çeşitlerin genetik yapısından kaynaklanabileceği düşünülmektedir.

\section{İlk koçan yüksekliği}

Denemede kullanılan silajlık mısır çeşitlerinin ilk koçan yüksekliğine ait ortalamalar ve oluşan gruplar Çizelge 3'de gösterilmiştir. En düşük ilk koçan yüsekliği $100.0 \mathrm{~cm}$ ile RESERVE çeşidinden elde edilmişken, en yüksek ilk koçan yüksekliği $156.1 \mathrm{~cm}$ ile 30 B 74 çeşidinden elde edilmiştir. SAMADA-07 $(155.5 \mathrm{~cm})$ ve AGA $(138.9 \mathrm{~cm})$ çeşidi ile arasındaki fark istatistiksel olarak önemsiz bulunmuştur. Çeşitlerin ilk koçan yüksekliği ortalaması $129.8 \mathrm{~cm}$ olarak belirlenmiştir (Çizelge 3). Ilk koçan yüksekliğinin önemi silajlık mısırda yatmaya karşı dayanıma etki eden bir kriter olmasından kaynaklanmaktadır. Çalışmada elde edilen ilk koçan yüksekliği değerleri, ilk koçan yüksekliğinin 1.372.08 m (Yıldız ve ark., 2017), 92-135 cm (Öner ve ark., 2011b), 99.80-150.63 cm (Öner ve Güneș, 2019) ve 110-153.3 cm (Han, 2016) arasında değiștiğini bildiren araştırıcıların bulgularıyla benzerlik göstermiştir.

\section{Yaprak sayısı}

Samsun ekolojik koşullarında 10 adet mısır çeşidi denemeye alınmış, elde edilen yaprak sayılarına ait ortalamalar Çizelge 3'de verilmiştir. Çizelge 3 incelendiğinde, en az yaprak sayısı 10.6 adet ile OTELLO çeşidinden elde edilmiş, en fazla yaprak sayısı ise 14.2 adet ile 30 B 74 ve 13.2 adet ile SAMADA-07 çeşitlerinden elde edimiştir. Çeşitlerin ortalama yaprak sayısı 11.9 adet bulunmuştur. Elde edilen bulgular yaprak sayısının yaprak sayının 10.41-14.25 adet (Yozgatlı ve ark., 2019) arasında değiştiğini bildiren literatürle benzerlik gösterirken, yaprak sayısının 13.6-14.4 adet (Han, 2006), 1318.46 adet (Ergül, 2008), 11.67-13.63 adet (Öner ve Güneş, 2019), 14.00-17.3 adet (Ayrancl, 1999), 12.415.1 adet (Şimşek, 2004), 13.25-15.40 adet (Vartanlı, 2006), 15.33-17.33 adet (Moralar, 2011), 12.3314.68 adet (Balmuk, 2012) ve 13.4-15.8 (Öktem ve Toprak, 2013) arasında değiştiğini bildiren literatürlerden düşük bulunmuş, yaprak sayısının 9.8-11.6 adet (Kabakçı, 2014) arasında değiştiğini bildiren literatürden yüksek bulunmuştur. Denemeden elde edilen yaprak sayısı değerleri literatürlerle karşılaştırıldığında, yaprak sayısının az ya da fazla olması, denemelerin yürütüldüğü lokasyonlardaki farklı iklim, toprak koşulları ile uygulanan kültürel işlemlerin farklılıklarından kaynaklanmış olabilir. Silajlık mısırda yaprak sayısının artışı silaj kalitesini doğru orantılı olarak artırdığı için hem yaprak sayısı hem de yaprak ağırlığı önemli bir kriterdir.

\section{Koçan sayısı}

Çalışmada kullanılan mısır çeşitlerinin koçan sayısına ait ortalamaları Çizelge 3'de gösterilmiştir. Mısır çeşitleri arasında koçan sayısı bakımından önemli bir farklılık bulunmamıştır. Deneme sonuçlarına göre koçan sayısı değerleri 1.0-1.4 adet arasında değişiklik göstermiş, genel ortalama 1.1 adet olarak belirlenmiştir (Çizelge 3). Orak ve İptaş (1999), silajlık misırda bitkinin en önemli kısmı yaprak ve yaprak sayısıdır. Bitkideki yaprak alanı ne kadar fazla ise bitkideki yaprak ağırlığı oranı da o denli yüksek olmaktadır. Silajlık mısır yetiştiriciliğinde bu özellikler çeşit seçiminde göz önüne alınacak en önemli parametrelerdir. Bir silajda kaliteyi artıran en temel kısım ise koçanın mutlaka silajda olmasıdır. Yaptıkları çalışmalarda, Yozgatlı ve ark. (2019) koçan sayısının 1.00-1.40 adet, Olgun (2011) 1.0-1.8 adet, Uzun ve ark. (2005) 1.00-1.01 adet, Gürel (2007) 1.0-1.08 adet, Küçük (2011) 1.0-1.10 adet arasında değiștiğini, Han (2016) ortalama koçan sayının 1.0 adet olduğunu bildirmişlerdir. Çalışmada belirlediğimiz koçan sayısı ile bu araştırıcıların bildirdiği sonuçlar arasında benzerlik olduğu görülmektedir.

\section{Sap çapı}

Mısır çeşitlerinin sap çapı ortalamaları 23.7-27.2 mm arasında değişiklik göstermiş ve ortalaması $25.7 \mathrm{~mm}$ olarak belirlenmiştir (Çizelge 3). Sap çapı ile ilgili olarak araştırmalardan elde ettiğimiz sonuçlar, 19.9$22.6 \mathrm{~mm}$ arasında değişen Çaçan ve İşikten (2019)'in sonucundan ve 17.21-23.23 mm arasında değișen Yozgatlı ve ark. (2019)'nın sonucundan yüksek, 22.89-29.62 mm arasında değişen Ergül (2008)'in sonucundan düşük bulunmuştur. Bulgularımız sap çapı 22.3-26.4 mm olan Han (2016) ile 23.44-27.84 mm olan Öner ve Güneş (2019)'in sonuçlarıyla uyum içerisindedir. Çalışmalar arasındaki farlılıkların kullanılan çeşitlerin genetik özelliğinden ve ugulanan kültürel işlemlerin farklılığından kaynaklandığı düşünülmektedir.

\section{Yaprak ağırlığı}

Denemede kullanılan mısır çeşitlerinin yaprak ağırlığına ait ortalama değerler ve oluşan gruplar ise Çizelge 4'de verilmiştir. En yüksek yaprak ağırlığı 
269.9 g ile SAMADA-07 çeşidinde belirlenmiş, $30 \mathrm{~B}$ 74 (256.9 g), DKC-955 (212.9 g) ve AGA (211.0 g) çeşitleri ile aynı istatistiki grup içerisinde yer almıştır.
En düşük yaprak ağırlığı 122.2 g ile OTELLO çeşidinden elde edilmiştir. Çeşitlere ait ortalama yaprak ağırlığı $200.8 \mathrm{~g}$ bulunmuştur (Çizelge 4).

Çizelge 4. Mısır çeşitlerinin yaprak ağırlığı, sap ağırlığı, koçan ağırlığı, kuru yaprak ağırlığı, kuru sap ağırlığı ve kuru koçan ağırlı̆̆ına ait ortalamaları.

\begin{tabular}{|c|c|c|c|c|c|c|}
\hline Çeşitler & Yaprak Ăg. & Sap A & Koçan Ăg. & Kuru Yap. Ăg. & Kuru Sap Ăg. & Kuru Koç. Ağ \\
\hline 30 B 74 & $256.9 \mathrm{ab}$ & 623.1 & $541.8 \mathrm{bc}$ & 86.7 & 120.7 & 229.7 \\
\hline $36 \mathrm{~K} 61$ & 173.5 cde & 392.4 & $474.9 \mathrm{bc}$ & 69.3 & 94.3 & 267.3 \\
\hline 72 MAY 80 & $191.3 \mathrm{bcd}$ & 513.3 & $575.1 \mathrm{bc}$ & 73.7 & 117.0 & 301.7 \\
\hline RX-9292 & $154.1 \mathrm{de}$ & 447.7 & 528.5 bc & 59.7 & 108.3 & 292.3 \\
\hline AGA & $211.0 \mathrm{abcd}$ & 554.8 & $644.7 \mathrm{~b}$ & 68.7 & 123.0 & 244.7 \\
\hline DKC-955 & $212.9 \mathrm{abcd}$ & 648.5 & $848.5 \mathrm{a}$ & 70.3 & 132.3 & 294.3 \\
\hline HİDO & $240.7 \mathrm{abc}$ & 482.2 & $667.3 \mathrm{ab}$ & 80.0 & 102.0 & 321.7 \\
\hline OTELLO & $122.2 \mathrm{e}$ & 345.6 & $424.8 \mathrm{c}$ & 59.0 & 109.0 & 274.0 \\
\hline RESERVE & $176.0 \mathrm{cde}$ & 410.4 & $595.8 \mathrm{bc}$ & 69.7 & 98.3 & 302.0 \\
\hline SAMADA-07 & $269.9 \mathrm{a}$ & 597.1 & 570.9 bc & 81.3 & 119.0 & 252.3 \\
\hline Genel ort. & 200.8 & 501.5 & 587.2 & 71.8 & 112.4 & 278.0 \\
\hline$\% \mathrm{VK}$ & 17.76 & 23.86 & 19.09 & 13.75 & 18.88 & 13.03 \\
\hline
\end{tabular}

Elde ettiğimiz yaprak ağırlığı değerleri; 139.2-186.0 g arasında değişen Sade ark. (2002)'nın sonucundan yüksek, 126.33-297.66 g arasında değişen Ergül (2008)'ün, 188.6-268.6 g arasında değişen Han (2016)'ın ve 310-450 g arasında değișen Yıldız ve ark. (2017)'nın sonuçlarından düşük bulunmuştur. Elde ettiğimiz yaprak ağırlığı değerinin diğer araştırıcıların değerlerinden farklı olmasının sebebinin; kullanılan çeşitlerin genetik özelliklerinden, mısır denemsi yapılan alanların farklı iklim ve toprak özelliklerine sahip olmasından ve hasat zamanalrının faklı olmasından kaynaklandığı düşünülebilir.

\section{Sap ağırlığı}

Çalışmada kullanılan çeşitlerinin sap ağırlığına ait ortalamaları Çizelge 4'de gösterilmiştir. Deneme sonuçlarına göre sap ağırlığı değerleri 345.6-648.5 g arasında değişiklik göstermiş, genel ortalama $501.5 \mathrm{~g}$ olarak belirlenmiştir (Çizelge 4). Yaptıkları çalışmalarda, Yıldız ve ark. (2017) sap ağırlığının 570-960 g, Ergül (2008) 394.00-699.33 g, Han (2016) 489.3-572.6 g olduğunu bildirmişlerdir. Çalışmada belirlediğimiz sap ağırlığının Yıldız ve ark. (2017) ile Ergül (2008)'ün bildirdiği sonuçlardan düşük, Han (2006)'ın bildirdiği sonuçtan yüksek olduğu görülmektedir.

\section{Koçan ağırlığı}

En düşük koçan ağırlığı 424.8 g ile OTELLO çeşidinden elde edilmişken, en yüksek koçan ağırlığı 848.5 g ile DKC-955 çeşidinden elde edilmiştir. HIDO (667.3 g) çeşidi ile arasındaki fark istatistiksel olarak önemsiz bulunmuştur. Çeşitlerin koçan ağırlı̆̆ ortalaması 587.2 g olarak belirlenmiștir (Çizelge 4).
Elde ettiğimiz koçan ağırlığı değerleri; 160-320 g arasında değişen Yıldız ve ark. (2017)'nın, 461.9$499.7 \mathrm{~g}$ arasında değişen Olgun (2011)'un ve 282.33$453.66 \mathrm{~g}$ arasında değişen Ergül (2018)'ün sonuçlarından yüksek bulunmuştur.

\section{Kuru yaprak ağırlığı}

Çizelge 4'e bakıldığında en düşük kuru yaprak ağırlığı $59.0 \mathrm{~g}$ ile OTELLO çeşidinde belirlenirken, en yüksek kuru yaprak ağırlığı 86.7 g ile 30 B 74 çeşidinde belirlenmiş, aralarındaki farklılıklar istatistiksel olarak önemli olmamıştır.

\section{Kuru sap ağırlığı}

Denemede kullanılan mısır çeşitlerine ait kuru sap ağırlığı ortalamaları ise Çizelge 4'de verilmiştir. Kuru sap ağırlığı üzerine çeşitlerin etkisi istatistiksel olarak önemli bulunmamıștır. En düşük kuru sap ağırlığı 94.3 g ile 36 K 61 çeşidinde belirlenirken, en yüksek kuru sap ağırlığı 132.3 g ile DKC-955 çeşidinde belirlenmiş, aralarındaki farklılıklar istatistiksel olarak önemli olmamıştır. Çeşitlerin kuru sap ağırlığı ortalaması 112.4 g olarak belirlenmiştir (Çizelge 4).

\section{Kuru koçan ağırlığı}

En yüksek kuru koçan ağırlığı 321.7 ile HIDO çeşidinde belirlenirken, en düşük kuru koçan ağırlığı $229.7 \mathrm{~g}$ ile 30 B 74 çeşidinde belirlenmiş, aralarındaki farklılıklar istatistiksel olarak önemli olmamıştır. Çeşitlerin kuru koçan ağırlığı ortalaması 278.0 g olarak belirlenmiștir (Çizelge 4).

\section{İncelenen özellikler arasındaki korelasyon}

Araştırmada incelenen parametreler arasındaki korelasyon analiz tablosu Çizelge 5'de verilmiştir. 
Çizelge 5 incelendiğinde yaprak sayısı ile çiçeklenme süresi $\left(\mathrm{r}=0.600^{* *}\right)$, yaprak ağırlığı ile çiçeklenme süresi ( $\left.\mathrm{r}=0.644^{* *}\right)$, bitki boyu ile ilk koçan yükseliği $\left(\mathrm{r}=0.595^{* *}\right)$, yaprak sayısı ile ilk koçan yüksekliği ( $r=0.691^{* *}$ ), yaprak ağırlığı ile ilk koçan yüksekliği $\left(\mathrm{r}=0.482^{* *}\right)$, yaprak ağırlığı ile bitki boyu( $\left.\mathrm{r}=0.609^{* *}\right)$, sap ağırlığı ile bitki boyu ( $r=0.527^{* *}$ ), yaprak ağırlığ ile yaprak sayısı ( $\left.\mathrm{r}=0.694^{* *}\right)$, sap ağırlığı ile yaprak sayısı ( $\left.\mathrm{r}=0.543^{* *}\right)$, kuru yaprak ağırlığı ile yaprak sayısı $\left(\mathrm{r}=0.575^{* *}\right)$, koçan ağırlığı ile koçan sayısı ( $r=0.743^{* *}$ ), kuru yaprak ağırlığı ile yaprak ağırlığ $\left(\mathrm{r}=0.697^{* *}\right)$ ve kuru yaprak ağırlığı ile sap ağırlığı $\left(\mathrm{r}=0.465^{* *}\right)$ arasında pozitif ve önemli $(\mathrm{P}<0.01)$ korelasyon bulunmuştur. Kuru koçan ağırlığı ile ilk koçan yüksekliği ( $\left.\mathrm{r}=-0.534^{* *}\right)$ ve sap çapı ile yaprak sayısı $\left(\mathrm{r}=-0.511^{* *}\right)$ arasında ise negatif ve önemli $(\mathrm{P}<0.01)$ korelasyon belirlenmiştir. Sap ağırlığı ile çiçeklenme süresi, sap ağırlığı ile ilk koçan yükseliği, kuru yaprak ağırlığı ile ilk koçan yüksekliği, yaprak ağırlığı ile koçan sayısı, kuru koçan ağırlığı ile koçan sayısı ve kuru koçan ağırlığı ile koçan ağırlığı arasında pozitif ve önemli $(\mathrm{P}<0.05)$ korelasyon bulunmuştur. Kuru koçan ağırlığı ile çiçeklenme süresi ve yaprak sayısı arasında negative ve önemli $(\mathrm{P}<0.05)$ korelasyon belirlenmişitir.

Çizelge 5. İncelenen özellikler arasındaki korelasyon tablosu

\begin{tabular}{|c|c|c|c|c|c|c|c|c|c|c|c|}
\hline & ÇS & IKY & BB & YS & KS & SÇ & YA & SA & KA & KYA & KSA \\
\hline IKY & 0.358 & & & & & & & & & & \\
\hline $\mathrm{BB}$ & 0.305 & $0.595^{* *}$ & & & & & & & & & \\
\hline YS & $0.600^{* *}$ & $0.691^{* *}$ & $0.617^{* *}$ & & & & & & & & \\
\hline KS & 0.196 & -0.166 & 0.024 & 0.012 & & & & & & & \\
\hline SÇ & -0.199 & -0.285 & -0.249 & $-0.511^{* *}$ & -0.047 & & & & & & \\
\hline YA & $0.644^{* *}$ & $0.482^{* *}$ & $0.609^{* *}$ & $0.694^{* *}$ & $0.431^{*}$ & -0.329 & & & & & \\
\hline SA & $0.402^{*}$ & $0.423^{*}$ & $0.527^{* *}$ & $0.543^{* *}$ & 0.279 & -0.159 & $0.664^{* *}$ & & & & \\
\hline $\mathrm{KA}$ & 0.274 & -0.091 & 0.261 & 0.169 & $0.743^{* *}$ & -0.127 & $0.466^{* *}$ & $0.534^{* *}$ & & & \\
\hline KYA & 0.336 & $0.412^{*}$ & $0.440^{*}$ & $0.575^{* *}$ & 0.165 & $-0.396^{*}$ & $0.697^{* *}$ & $0.465^{* *}$ & 0.123 & & \\
\hline KSA & 0.243 & 0.278 & 0.306 & 0.306 & 0.145 & -0.078 & 0.261 & 0.350 & 0.345 & 0.045 & \\
\hline KKA & $-0.380^{*}$ & $-0.534^{* *}$ & -0.296 & $-0.376^{*}$ & $0.439^{*}$ & -0.025 & -0.117 & -0.078 & $0.402^{*}$ & -0.004 & -0.171 \\
\hline
\end{tabular}

ÇS: Çiçeklenme Süresi, BB: Bitki Boyu, İKY: İlk Koçan Yüksekliği, YS: Yaprak Sayısı, KS: Koçan Sayısı, SÇ: Sap Çapı, YA: Yaprak Ağırlı̆̆ı, SA: Sap Ağırlı̆̆ı, KA: Koçan Ağırlığı, KYA: Kuru Yaprak Ağırlı̆̆ı, KSA: Kuru Sap Ağırlığı, KKA: Kuru Koçan Ağırlı̆̆ı.

\section{Sonuç ve Öneriler}

Samsun Çarşamba ekolojik koşullarında yetiştirilen silajlık mısır (Zea mays L.) çeşitlerinde bazı bitkisel özelliklerinin belirlenmesi amacıyla yürütülen tek yıllık çalışma sonuçlarına göre, koçan sayısı, sap çapı, sap ağırlığı, kuru yaprak ağırlığı, kuru sap ağırlığı ve kuru koçan ağırlığı bakımından çeşitler arasındaki farklılık istatistiksel olarak önemli bulunmamıștır. Bununla birlikte çiçeklenme süresi, bitki boyu, ilk koçan yüksekliği, yaprak sayısı ve koçan ağırlığı bakımından çeşitler arasındaki farkın önemli veya çok önemli olduğu belirlenmiştir. Elde edilen verilerin genel olarak değerlendirilmesi sonucunda çiçeklenme süresi bakımından Otello çeşidi öne çlkarken, bitki boyu, ilk koçan yüksekliği, yaprak sayısı ve yaprak ağırlığı bakımından Samada 07 ve 30 B 74 çeşitlerinin bölge için diğer çeşitlerden daha ümitvar olduğu düşünülmektedir. Kesin öneriler yapabilmek için bu çalışmaların bir kaç yıl daha kapsamlı olarak yapılmasına ihtiyaç vardır.

\section{Kaynaklar}

Alçiçek, A., \& Karaayvaz, K. (2003). Sı̆̆ır besisinde mısır silajı kullanımı. Animalia, 203: 68-76.
Akdeniz, H., Yılmaz, İ., Antiç, N., \& Zorer, Ş. (2003). Bazı mısır çeşitlerinde verim ve yem değerleri üzerine bir araştırma. Yüzüncü Yıl Üniversitesi, Ziraat Fakültesi Dergisi, 14 (1): 47-51.

Anonim, (2019). TÜİK Raporları Ankara.

Argillier 0, Méchin V, \& Barriére T. 2000. Inbred line evaluation and breeding for digestibility-related traits in forage maize Crop. Sci., 40:1596-2000.

Ayrancı, R. (1999). Konya ekolojik şartlarında yetiştirilebilecek at dişi melez mısır çeşitlerinin belirlenmesi. Yüksek Lisans Tezi. Selçuk Üniv Fen Bilimleri Ens. Tarla Bitkileri Anabilim Dalı. Konya.

Balmuk, Y. (2012). Konya Yunak koşullarında ikinci ürün olarak yetiştirilebilecek silajlık mısır çeșitlerinin verim ve verim özelliklerinin belirlenmesi. Yüksek Lisans Tezi. GOP Üniv Fen Bilimleri Ens. Tokat.

Çaçan, E. \& İşikten, S. (2019). Bingöl ili ekolojik koşullarında bazı silajlık mısır çeşitleri için uygun ekim zamanının belirlenmesi. Türkiye Tarımsal Araştırmalar Dergisi, 6(1):39-49, ISSN: 2148-2306.

Çete, N. \& Sarıcan, C. (1998). Silajlık yem bitkileri üretim ve silaj yapımı. U.S. Grains Council.

Bilgiç Ş., Sade, B., Süleyman Soylu, S., Bilgiçli, N., Cerit, İ., Öz, A., Cengiz, R., \& Özkan, İ. (2012). Misır Raporu.Ulusal Hububat Konseyi, Konya. 
Emeklier, H.Y. (2002). Altın tanesi misırın kimyası ve endüstride kullanımı. Üretimden tüketime mısır paneli tebliğleri. S 100-124. T. C. Sakarya Valiliği,

Eralp, Ö. (2007). Menemen koşullarında ikinci ürün tarımına uygun silajlı mısır çeşitlerinin belirlenmesi. Yüksek Lisans Tezi, Adnan Menderes Üniversitesi, Fen Bilimleri Enstitüsü, Aydın.

Ergül, Y. (2008). Silajlık mısır çeșitlerinin önemli tarımsal ve kalite özelliklerinin belirlenmesi. Yüksek Lisans Tezi, Selçuk Üniversitesi, Fen Bilimleri Enstitüsü, Tarla Bitkileri Anabilim Dalı, Konya.

Geçit H.H., Çiftçi C.Y., Ünver İkincikarakaya S., \& Kaya M. (2009). Tarla Bitkileri. A.Ü.Z.F. Ders Kitabı: 521,

Gençtürk, F. (2007). Bazı silajlık mısır çeşitlerinin Erzurum ovası koşullarında yetiştirilme olanakları üzerine bir araştırma. Yüksek Lisans Tezi, Atatürk Ün, FBE, Tarla Bitkileri Anabilim dalı. Erzurum.

Gürel, F. (2007). Kastamonu ekolojik şartlarına uygun silajlık mısır (Zea mays L.) çeşitlerinin belirlenmesi. Yüksek Lisans Tezi, GOP Üni, Fen Bilimleri Enstitüsü, Tokat.

Han, E. (2016). Bazı mısır çeşitlerinin dane verimleri ile silaj ve kalite özelliklerinin belirlenmesi. Yüksek Lisans Tezi, Ordu Üniversitesi, Fen Bilimleri Enstitüsü, Tarla Bitkileri Anabilim Dalı, Ordu.

Kabakçı, S. (2014). Iğdır ekolojik şartlarına uygun silajlık mısır çeşitlerinin belirlenmesi. Yüksek Kisans Tezi, Iğdır Üniversitesi, Fen bilimleri Enstitüsü, Iğdır.

Kapar, H., \& Öz. A. (2006). Bazı mısır çeşitlerinin Orta Karadeniz Bölgesi'nde performanslarının belirlenmesi, Ondokuz Mayıs Üniversitesi Ziraat Fakültesi Dergisi, 21 (2), 147-153.

Kavut, Y.T. (2009). Farklı Lokasyonlarda Yetiştirilen Kimi Mısır ve SorgumxSudanotu Melez Çeşitlerinin Verim ve verim Özellikleri Üzerinde Araştırma. Doktora Tezi, Ege Üniversitesi Fen Bilimleri Enstitüsü, İzmir.

Küçük, B. (2011). Bazı silajlık mısır çeşitlerinde morfolojik özelliklerin ve yem verimlerinin belirlenmesi. Yükske Lisans Tezi. Ankara Üniversitesi. Fen Bilimleri Enstitüsü. Ankara.

Moralar, E. (2011). Tekirdağ ilinde yetiştirilen bazı silajlık mısır çeşitlerinde gelişme sürecinin belirlenmesi ve verimliliklerinin tespiti. Yüksek Lisans Tezi. Namık Kemal Üniversitesi. Fen Bilimleri Enstitüsü. Tarla Bitkileri Anabilim Dalı. Tekirdağ.

Olgun, F. (2011). Silajlık melez mısır çeşitlerinin farklı hasat zamanının verim, verim unsurları ve kalite üzerine etkisi. Yüksek Lisans Tezi, Selçuk Ünivi, Fen Bilimleri Ens, Tarla Bitkileri Anabilim Dalı, Konya.

Orak, A. \& İptaş, S. (1999). Silo yem bitkileri ve silaj. Çayırmera amenajmanı ve ıslahı. Mera Kanunu eğitim ve Uygulama El Kitabı 1. T.C. Tarım ve Köy İşl. Bak.
Öktem, A. \& Toprak, A. (2013). Çukurova koşullarında bazı atdişi misır genotiplerinin verim ve morfolojik özelliklerinin belirlenmesi. Harran Üniversitesi. Ziraat Fakültesi Dergisi, 17(4): 15-24. Şanlıurfa.

Öner, F. (2015). Determination of chemical quality parameters with yield and yield components of maize (Zea mays L.) hybrids according to various FAO maturity groups. Tekirdağ Ziraat Fakültesi Dergisi 12 (1): 1-7.

Öner, F., Aydın, İ., Sezer, İ., Gülümser, A.,\& Mut, Z. (2011b). Samsun koşullarında bazı hibrit mısır çeşitlerinin verim ve kalite özelliklerinin belirlenmesi. Türkiye 9. Tarla Bitkileri Kongresi, Bursa (551-554).

Öner, F., Aydın, İ., Sezer, İ., Gülümser, A., Özata, E., \& Algan, D. (2011a). Bazı silajlık mısır çeşitlerinde verim ve kalite özelliklerinin belirlenmesi. Türkiye 9. Tarla Bitkileri Kongresi, Bursa (453-456).

Öner, F. (2017). Ordu ili yerel misır (Zea mays L.) genotiplerinin morfolojik karakterizasyonu. Tarım ve Yaban Hayatı Bilimleri Dergisi 3(2):108-119.

Öner, F. \& Güneş, A. (2019). Bazı mısır (Zea mays L.) çeşitlerinin silajlık verim ve kalite özelliklerinin belirlenmesi. Tekirdağ Ziraat Fakültesi Dergisi. 16(1), 42-50. DOI:10.33462/jotaf.516865.

Öz, A., Kapar, H., \& Dok, M. (2017). Karadeniz Tarımsal Araștırma Enstitüsü Yayınları.

Sade, B., Akbudak, M. A., Acar, R., \& Arat, E. (2002). Konya ekolojik şartlarında silajlık olarak uygun mısır çeşitlerinin belirlenmesi. Hayvancılık Araştırma Dergisi, 12 (1): 17-22. Konya.

Şimşek, D. (2004). Antalya şartlarında ikinci ürün olarak ekilebilecek silajlık hibrit mısır çeşitlerinin bazı tarımsal özelliklerinin belirlenmesi. Yüksek Lisans Tezi. Selçuk Üniv Fen Bilimleri Ens Tarla Bitkileri Anabilim Dalı. Konya.

Uzun, A., Karasu, A., Turgut, İ., Çakmak, F., \& Turan, M. (2005). Bursa koşullarında ekim nöbeti sistemlerinin mısırın verim ve verim öğeleri üzerine etkisi. Uludağ Üniversitesi Dergisi, 19 (2): 61-68. Bursa.

Vartanlı, S. (2006). Ankara koşullarında hibrit mısır çeşitlerinin verim ve kalite özelliklerinin belirlenmesi. Yüksek Lisans Tezi. A. Ü. FBE Ankara.

Yıldız, H., İlker, E., \& Yıldırım, A. (2017). Bazı silajlık mısır (Zea mays L.) çeşit ve çeşit adaylarının verim ve kalite özelliklerinin belirlenmesi. Süleyman Demirel Üniversitesi, Ziraat Fakültesi Dergisi. 12 (2), 81-89,

Yozgatll, O., Başaran, U., Gülümser, E., Mut, H., Çopur \& Doğrusöz, M. (2019). Yozgat ekolojisinde bazı mısır çeşitlerinin morfolojik özellikleri, verim ve silaj kalit.. KSÜ Tarım ve Doğa Derg. 22(2):170-177. 